\title{
DETERMINATION OF TOTAL ACCUMULATED RAINFALL, GLOBAL RADIATION, EVAPOTRANSPIRATION AND DEGREE-DAYS ORIGINATED FROM THE ECMWF MODEL TO SUGAR CANE CROP
}

\author{
RAFAEL A. MORAES ${ }^{1}$, JANSLE V. ROCHA ${ }^{2}$, RUBENS A. C. LAMPARELLI ${ }^{3}$
}

\begin{abstract}
The climate variability between the growth and harvesting of sugar cane is very important because it directly affects yield. The MODIS sensor has characteristics like spatial and temporal resolution that can be applied to monitoring of vegetative vigor variability in the land surface and then, temporal profiles generation. Agro meteorological data from ECMWF model are free and easy to access and have a good representation of reality. In this study, we used the period between sugar cane growth and harvest in the state of Sao Paulo, Brazil, from temporal profiles selecting of NDVI behavior. For each period the precipitation, evapotranspiration, global radiation, length (days) and degree-days were accumulated. The periods were presented in a map format on MODIS spatial resolution of 250 meters. The results showed the spatial variability of climate variables and the relationship to the reality presented by official data.
\end{abstract}

KEYWORDS: agro meteorological variable, ECMWF, MODIS, sugar cane .

\section{DETERMINAÇÃO DO TOTAL ACUMULADO DE PRECIPITAÇÃO, RADIAÇÃO GLOBAL, EVAPOTRANSPIRAÇÃO DE REFERÊNCIA E GRAUS-DIAS ORIUNDOS DO MODELO ECMWF PARA O CULTIVO CANA-DE-AÇÚCAR}

RESUMO: O conhecimento da influência da variabilidade climática no período entre o crescimento e a colheita da cana-de-açúcar é de grande importância, pois afeta diretamente a produtividade. O sensor MODIS, devido a sua resolução espacial e temporal, permite o monitoramento da variabilidade do vigor vegetativo na superfície terrestre e, por conseguinte, a geração de perfis temporais deste comportamento a partir de seus produtos. Dados agrometeorológicos obtidos pelo modelo ECMWF, além de gratuitos e de fácil acesso, apresentam boa representatividade da realidade. Neste trabalho, foram utilizados intervalos de crescimento e colheita obtidos pela seleção de perfis temporais de NDVI com comportamento de cana-de-açúcar no Estado de São Paulo. A partir destes, foram acumulados, dentro de cada período, a soma da precipitação pluvial, evapotranspiração de referência, radiação global e comprimento do período em dias. Além disso, foi feito o somatório de graus-dia da cana-de-açúcar. Todos os resultados foram apresentados em formato de mapa, na resolução espacial do sensor MODIS de 250 metros. A análise dos resultados mostrou que foi possível identificar a variabilidade espacial das variáveis climáticas e sua relação com a realidade apresentada por órgãos oficiais.

PALAVRAS-CHAVE: variáveis agrometeorológicas, ECMWF, MODIS, cana-de-açúcar.

\section{INTRODUCTION}

Currently Brazil accounts for approximately $43 \%$ of the production of sugar cane in the world (FAOSTATS, 2012), being the state of São Paulo responsable by 59.5\% of this total (IBGE, 2012). This culture is targeted to the production of sugar and ethanol, the latter being a sustainable alternative to fossil fuel (TRIANA, 2011).

\footnotetext{
${ }^{1}$ Dr. em Eng. Agrícola do Programa de Pós-Graduação da Feagri/UNICAMP, Campinas-SP, rafagricola@yahoo.com.br

${ }^{2}$ Dr. em Sensoriamento Remoto, Prof. Associado, Programa de Pós-Graduação da Feagri/UNICAMP, Campinas - SP, jansle.rocha@feagri.unicamp.br

${ }^{3}$ Dr. em Eng. de Transportes, Pesquisador do Núcleo Interdisciplinar de Planejamento Energético - NIPE, Professor do Programa de Pós-Graduação da Feagri/UNICAMP, Campinas-SP, rubens.lamparelli@gmail.com 
The climatic conditions are primarily responsible for the variability of agricultural production. Among the climatic elements, temperature, solar radiation and rainfall are crucial to the development of sugar cane. (MARIN et al., 2008). Thus, knowledge of the variation of these variables during the cultivation of sugar cane, associated with agrometeorological yield models, allows prediction about their productivity (PEREIRA et al., 2002).

Generally agrometeorological data comes from conventional or automatic weather stations. However, frequently, these data may have errors or are difficult to access. Thus, agrometeorological data from global models such as ECMWF (European Centre for Medium-Range Weather Forecast) may turn out to be an alternative.

The ECMWF model assumes in its calculations the data from weather stations around the world, weather radars, satellites, among other sources. This information used in equations describing the characteristics of the atmosphere and produce as a result, meteorological and agrometeorological parameters, worldwide. These parameters are processed and transferred via MeteoConsult Company, for the Joint Research Centre (JRC), Research Centre of the European Commission, which makes available for free on the internet (PERSON \& GRAZZIANI, 2007).

Besides the agro-meteorological monitoring, the identification of the dynamics of the agricultural cultivation process is of great importance. One of the ways to do so is the use of GIS techniques and remote sensing. The Moderate Resolution Imaging Spectroradiometer (MODIS) is a sensor on board of Terra (EOS AM) and Aqua (EOS PM) satellites providing suitable images for monitoring of vegetation cover. XAVIER et al. (2006) and AGUIAR (2008) showed that it is possible the identification and monitoring of sugar cane from the MODIS sensor. MORAES (2012a), from the NDVI multi-temporal images analysis of this sensor, it was identified and classified sugar cane areas in their respective stages of cultivation.

Thus, in different time periods identified between growth and harvest sugar cane in the state of São Paulo, and using data from the ECMWF and MODIS, the sums of precipitation, evapotranspiration, global radiation and degree-day were quantified. All these results were presented in map format providing a spatial view of the results obtained.

\section{MATERIALS AND METHODS}

The study was conducted for the whole area of the state of São Paulo, considering periods between 2006/2007, 2007/2008, 2008/2009, 2009/2010. Each period starts in May of the first year and ends in November of the following year, in order to cover the period with areas from planting and sprouting until the harvest of the following year, in the state of São Paulo.

Were used for this study, agro-meteorological database of global radiation $\left(\mathrm{kJ} \mathrm{d}^{-1} \mathrm{~m}^{-2}\right)$, average air temperature $\left({ }^{\circ} \mathrm{C}\right)$, rainfall $(\mathrm{mm})$ and reference evapotranspiration $(\mathrm{mm})$ from the global model ECMWF (European Centre for Medium -Range Weather Forecast). This has a spatial resolution of $0.25^{\circ}$ (degree) and temporal of 10 days and it is in point shape format. MORAES et al. (2012b) compared maximum and minimum air temperature data, and precipitation derived from surface stations with data from the ECMWF model for the state of São Paulo and found satisfactory results, with most results with the correlation coefficient $\left(\mathrm{R}^{2}\right)>0.60$; (Willmott index) $\mathrm{d}>0.7$; square root of the mean error (SRME $<5^{\circ} \mathrm{C}$ and $<50 \mathrm{~mm}$; Systematic Error (Se) $<5^{\circ} \mathrm{C}$ and $<24 \mathrm{~mm}$, and therefore may be used directly.

Besides the agro-meteorological data, four shades with the mapping of sugar cane for the years 2006/2007, 2007/2008, 2008/2009, 2009/2010 and shade mapping of the temporal variation of growth and harvest dates for each pixel from NDVI data of the MODIS sensor, MOD13Q1 product in TIFF format, spatial resolution of $0.002299^{\circ}$ (degree) and temporal of 16 days, as described by MORAES (2012a). Thus, for each considered interval, we have 35 shades of temporal variation of growth dates until the sugar cane harvest, where each pixel has an image / start date and an image / end date, starting in the growth and ending in the harvest. 
Knowing that the temporal resolution of agro-meteorological data is every 10 days and data shades are every 16 days, the adequacy of the data of the ECMWF model was made for this resolution. Thus the data, first available in decades, were transformed into daily, where the values of mean air temperature were repeated every day; the precipitation, global radiation and evapo -transpiration were divided by 10 and repeated at daily resolution. Thus, the average air temperature was recalculated by selecting values every 16 days, for precipitation, global radiation and evapotranspiration the sum were made and in the end the data were exported to the point shape format.

All phases of the study were performed using spreadsheets in Microsoft Excel, the ENVI 4.5 (The Environment for Visualizing Images) software from the generation of routines in IDL (Interactive Data Language) version 7.0 and the ESRI Arc Map 9.3.1 to generate the maps. The stages of the study are presented in the following flowchart (Figure 1).

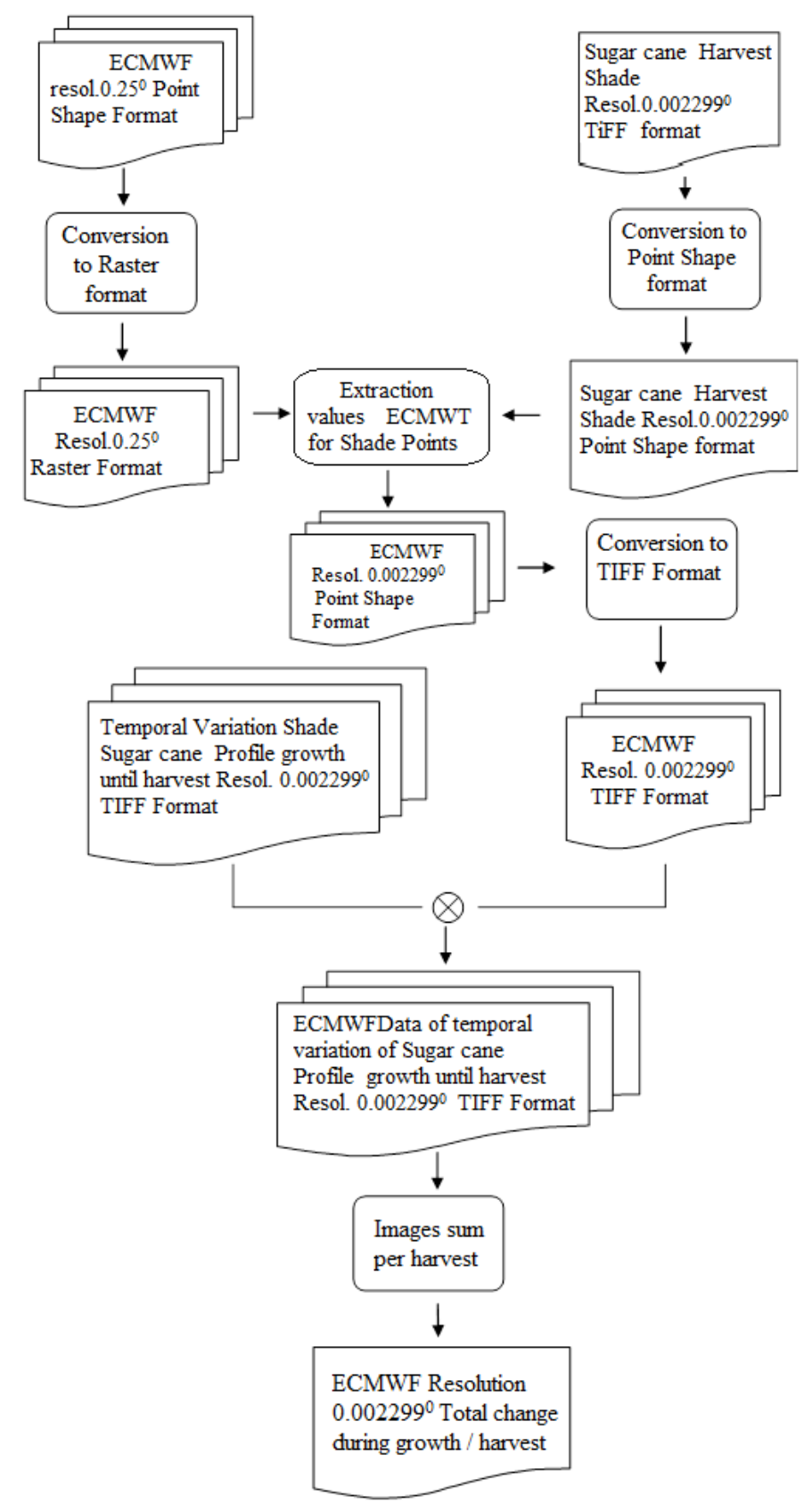

FIGURE 1. Study flowchart. 
After transformation of the temporal resolution data of the ECMWF, the conversion of the spatial resolution of those for the shades resolution of $0.02299^{\circ}$ in TIFF format was made. For this, initially the ECMWF data point shape was transformed to raster image in $0.25^{\circ}$.

The transformation of these values in the spatial resolution of $0.002299^{\circ}$ was taken converting every shade of sugar cane, which has the spatial resolution required and TIFF format, for point shape format. From each location of these points, localized values of those points on each raster image for each agro-meteorological variable were extracted. After this procedure, with each point shape having the raster value of ECMWF, this was again converted into TIFF format.

The shades of the length variation of the temporal profile determine the dates of growth until the sugar cane harvest in the period considered. These present value 1 (one) when positive for sugar cane and 0 (zero) for absence. The initial shade representing the date of the first image of the MOD13Q1 product, in May, shows part of pixels where the sugar cane began the growth. In the follow image are presented new pixels where the sugar cane growth began on the date of this image, in addition to the same showed in the previous shade and so on in a cumulative manner. It is considered as sugar cane growth until the $14^{\text {th }}$ image where the $15^{\text {th }}$ shows all positive pixels to sugar cane, according to the classification of the shade.

From the $16^{\text {th }}$ image starts the exclusion of pixels which represent the harvest and this will be zero until the last image. This exclusion follows cumulatively between January and November, that is, from the $16^{\text {th }}$ to the $35^{\text {th }}$ image.

With the full temporal profile from the growth to the sugar cane harvest represented by the value 1 in each pixel, these images were multiplied by previously ones obtained for each agrometeorological variable, in the same dates. Thus, temporal profiles from agro-meteorological variables of ECMWF were obtained within the range of a sugar cane cycle, from the growth until harvest in the studied period, excluding the other pixels by the zero value of the shades.

In possession of the temporal profiles of each agro-meteorological variable, it was obtained the cumulative total rainfall, global radiation and reference evapotranspiration. Thus was made the sum of all the images obtained in the multiplication aforementioned. Furthermore, it was obtained the total cycle length in days, of each pixel from the growth to the harvest. For this was done the sum of the shades of the temporal profiles of growth / harvest (which have values 0 and 1) and after obtaining the sum image, each pixel was multiplied by 16 , representing the total days each image showed.

To obtain the total degree- days for sugar cane in the range of growth and harvest of each pixel was considered the equation:

Where,

$$
D D=\left(T_{\text {mean }}-T_{\text {base }}\right)
$$

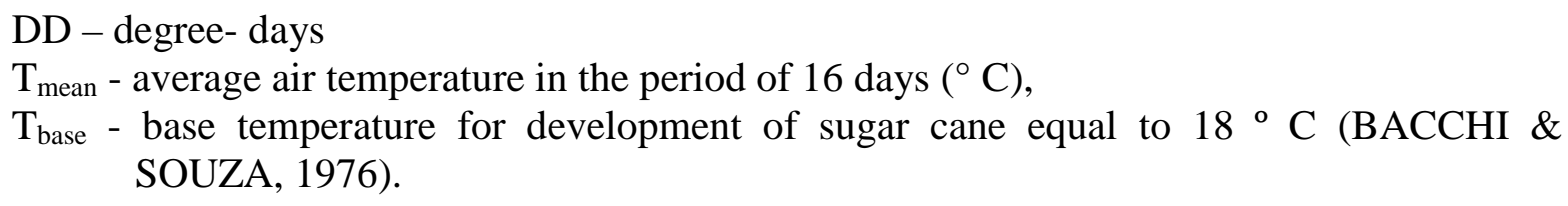

For negative values of DD, they were considered equal to zero on the relevant date of the image in question. Thus, after obtaining the temporal profile of DD images, the sum was made from images in order to obtain the total DD for the cycle.

\section{RESULTS AND DISCUSSION}

Cumulative totals of precipitation, evapotranspiration and global radiation for the interval between the dates of sugar cane growing and harvesting are shown in Figures 2, 3 and 4 
respectively. In Figure 5, is shown the time interval between growth and harvest in the scale of the number of days and in Figure 6 the sum of degree-days for each period.

The sum of precipitation (Figure 2), is verified for sugar cane harvested in 2007 a predominance of values accumulated between 1500 and $1750 \mathrm{~mm}$ in most of the shade. For the interval between 2007 and 2008, despite a cumulative precipitation between 1500 and $2000 \mathrm{~mm}$ in the northern part of the state, a decrease in the central part and Midwest between 1000 and 1500 $\mathrm{mm}$ is verified. At harvest occurred in 2009, just in the northeast part of the state had accumulated between 1250 and 1500 and the remainder between 750 and $1250 \mathrm{~mm}$. In the 2010 harvest the rain was lower in the northeastern of the state $(750-1250 \mathrm{~mm})$ and higher in the remaining (1250-1750 $\mathrm{mm})$.

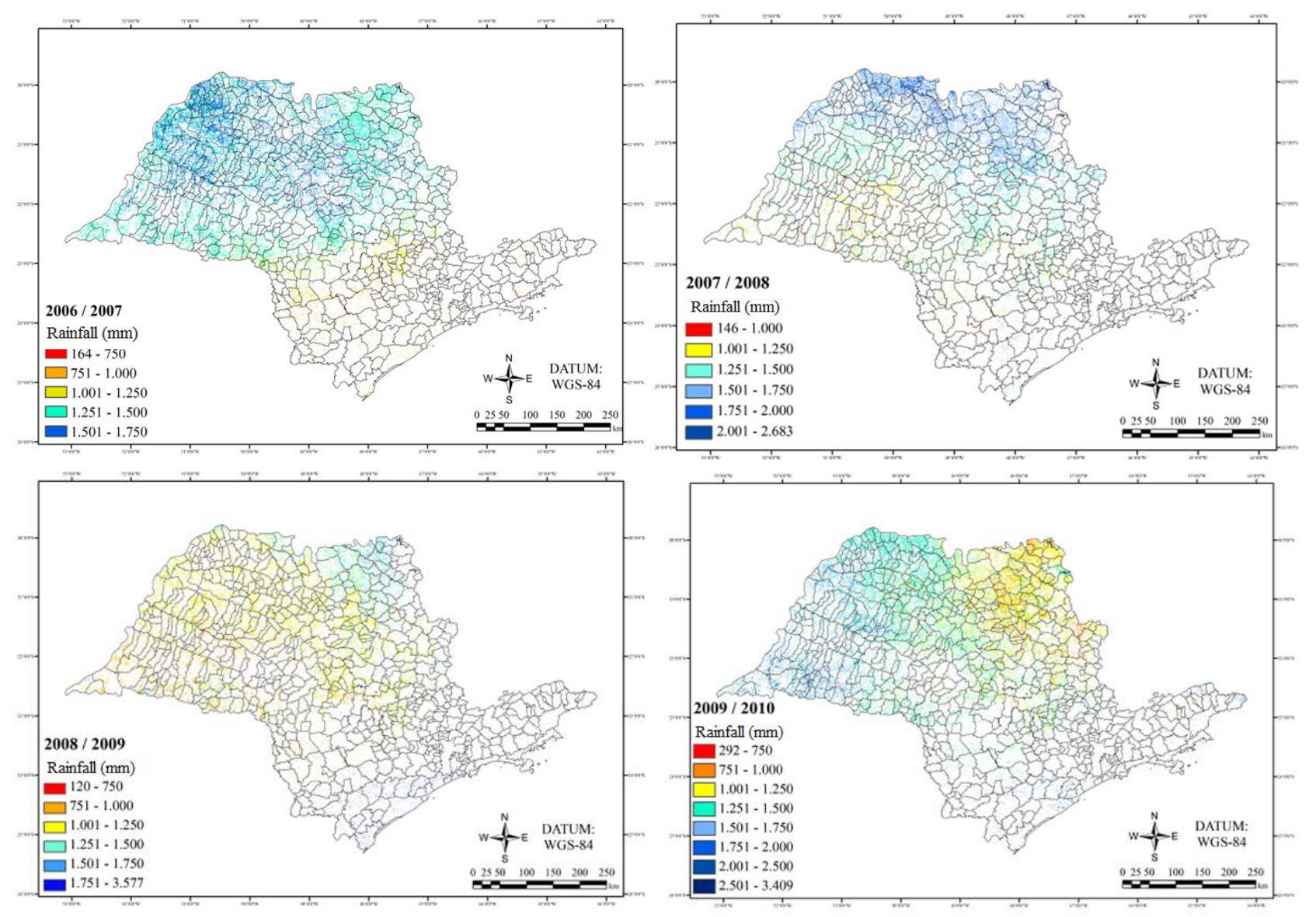

FIGURE 2. Accumulated value of rainfall in ranges of sugar cane growth and harvest for the years 2006/2007, 2007/2008, 2008/2009 and 2009/2010.

The accumulated reference evapotranspiration (Figure 3), derived from the ECMWF model, presents for the years studied values close to or below the precipitation. But for the year 2006/2007 the northwest part of the state had accumulated reference evapotranspiration greater than the rainfall in some points, reaching $2000 \mathrm{~mm}$. In this region the accumulated global radiation (Figure 4) reached the highest values between $5,000,000$ and $10,000,000 \mathrm{~kJ} \mathrm{~m}^{-2}$. However, this radiant energy generally, varied with accumulated between 2,500,000 and 7,500,000 $\mathrm{kJ} \mathrm{m}^{-2}$. 

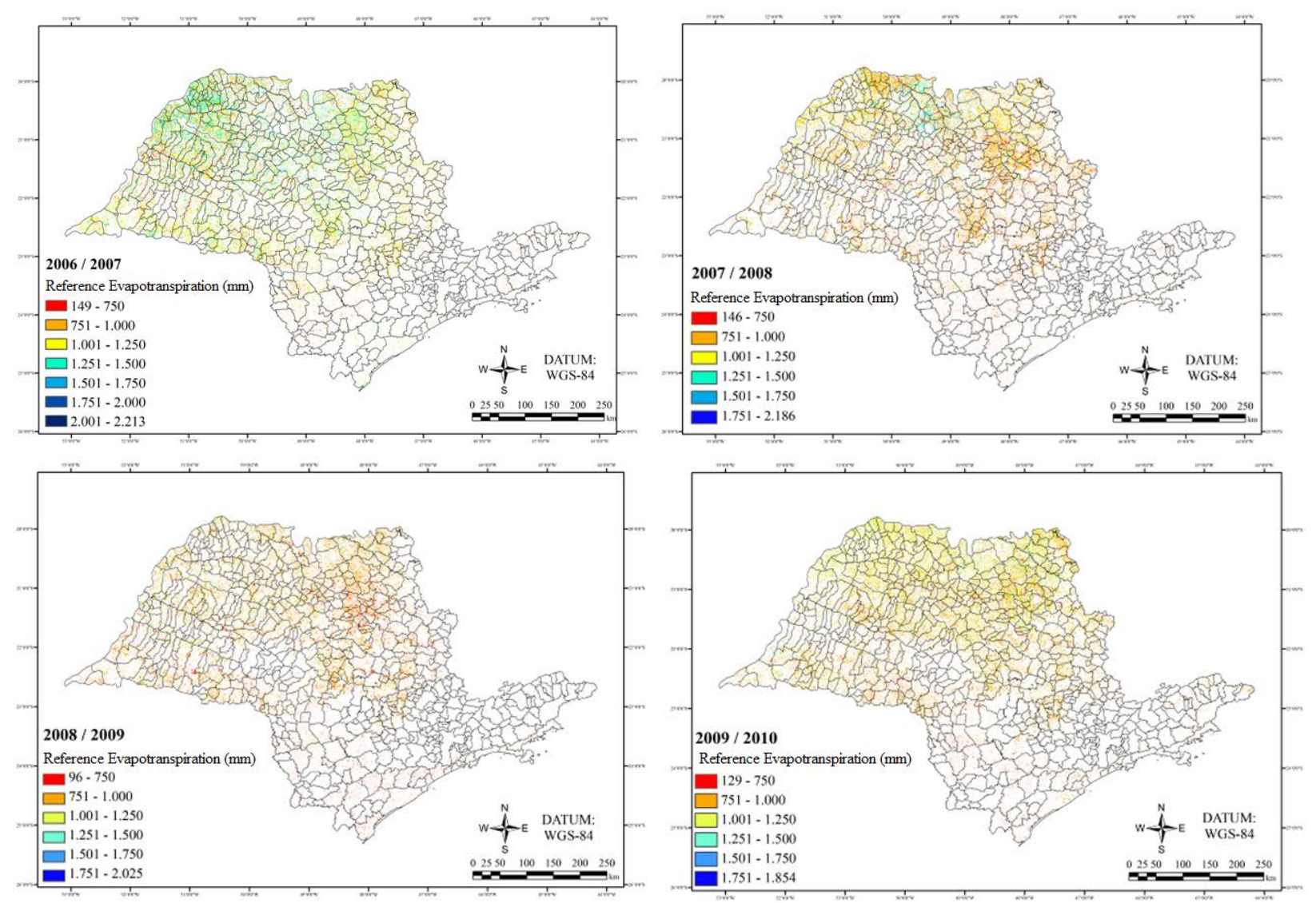

FIGURE 3. Accumulated value of reference evapotranspiration in ranges of sugar cane growth and harvest in 2006/2007, 2007/2008, 2008/2009 and 2009/2010.
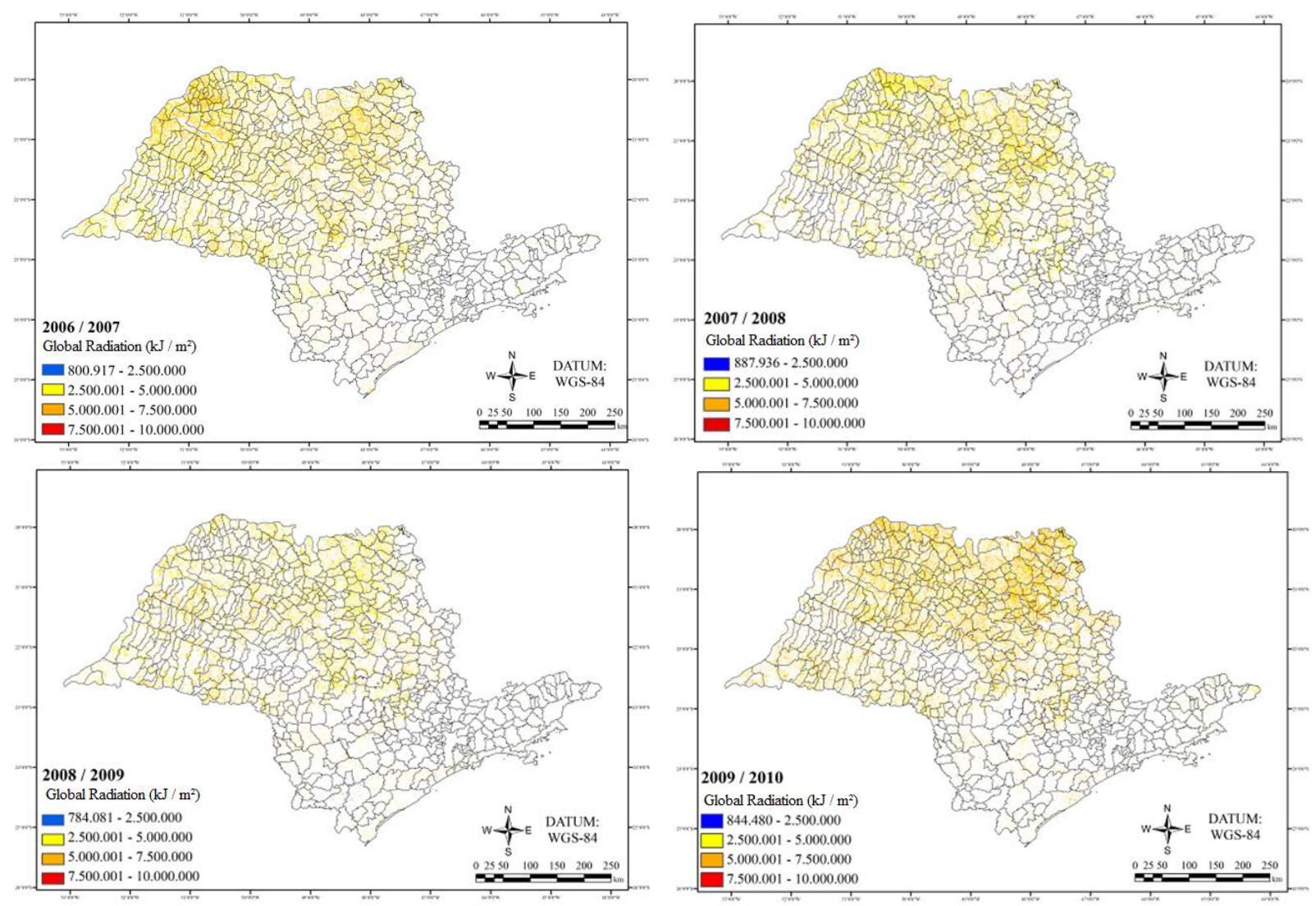

FIGURE 4. Accumulated value of global radiation in ranges of sugar cane growth and harvest in 2006/2007, 2007/2008, 2008/2009 and 2009/2010 obtained from the methodology applied. 
According to DOORENBOS \& KASSAM (1979), the sugar cane has water requirement between 1500 and $2500 \mathrm{~mm}$, evenly distributed during the crop cycle. Changes below this range may affect their productivity. Moreover, according to RODRIGUES (1995), being a C4 plant, is considered highly efficient in converting radiant energy into chemical energy, and the air temperature is extremely important because it exerts great influence on the stems growth, with an optimum temperature range between $25^{\circ}$ and $35^{\circ} \mathrm{C}$. Thus, the cumulative global radiation showed no major changes since the energy requirements within each cycle and period were reached.

In relation to water requirements, rainfall decreases from the 2007/2008 period to the 2009/2010 period. . The critical period was the 2008/2009 year, where most of the time the total rainfall was about $250 \mathrm{~mm}$ below the minimum recommended. This result confirms the justification given by MORAES (2012a) where the mapped area in 2008/2009 was smaller, because according to the author, mapping was done by analyzing the way of the NDVI temporal profiles, being selected the ones that presented the behavior of sugar cane crop. This profile mischaracterized in its way, either by reducing the vegetative vigor or by the harvested areas in an incomplete way, damaged the mapping.

CONAB (2009a, 2009b) confirms that in the harvest of 2009, there was an amount of rainfall above-normal in the months of July, August, September and October, during which the time of grinding is more intense and the sugar cane has higher concentration of saccharose. This affected the milling process with interruptions in harvesting and reduction in the concentration of TRS (Total Recoverable Sugars). In addition, there was about 20 million tons of sugar cane that were not harvested, staying to the next period (bisada cane). As UDOP (2012), the productivity for the studied years for the center-south region of Brazil, showed values of 75.4 ton / ha (2006/2007), 84.9 ton / ha (2007/2008) and 81. 2 ton / ha (2009/2010). The delay in 2008 and the problems at harvest in 2009 also influenced the cycle length of the growing and the harvest period. According to Figure 5, the crop in 2007 was normal, with periods longer than 360 days. However, in 2008, there is a shortening of that cycle, worsening in 2009 and only increasing the harvest again in 2010.
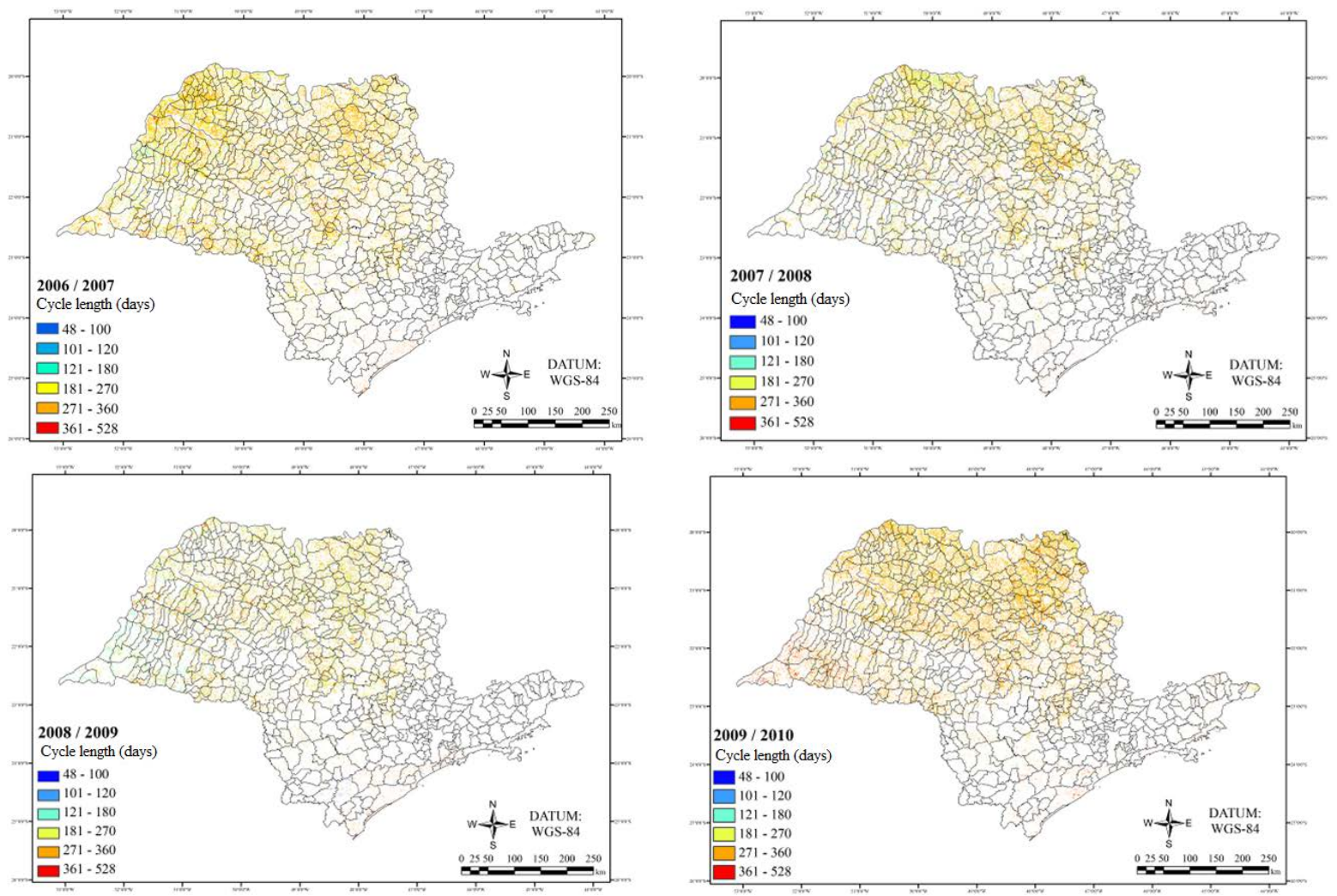

FIGURE 5. Accumulated value of days in ranges of sugar cane growth and harvest in 2006/2007, 2007/2008, 2008/2009 and 2009/2010. 
In the period 2006/2007, according to CONAB (2007) there were no problems on the production of sugar cane intended for the ethanol industry. As for the 2008 harvest, high levels of rainfall in the initial period caused delay in the schedule of sugar cane grinding and eventually lower harvested volume (CONAB 2008). In the 2010 harvest (CONAB, 2010), the weather did not affect the culture, favoring both the harvesting operations as the concentration of TRS. However, the lack of rainfall during the growing period harmed the sprouting and the development of sugar cane for the harvest in 2011, shortening the crop period (CONAB, 2011).

Figure 6 shows the sum of degree-days for sugar cane considering a basal temperature of $18^{\circ}$ C. ALMEIDA et al. (2008) analyzed the vegetative growth of sugar cane in relation to water availability and thermal units for Alagoas, it was found values between 1500 and 2015 DD in plantcane and 950 and 180 DD in ratoon- cane. . These values were found in this research, highlighting that these were followed by the problems presented from the 2008 harvest where high values of DD (2000-2500) in the period of 2006/2007 were declining in the harvests of 2008 and 2009, increasing again only in the period of 2009/2010.
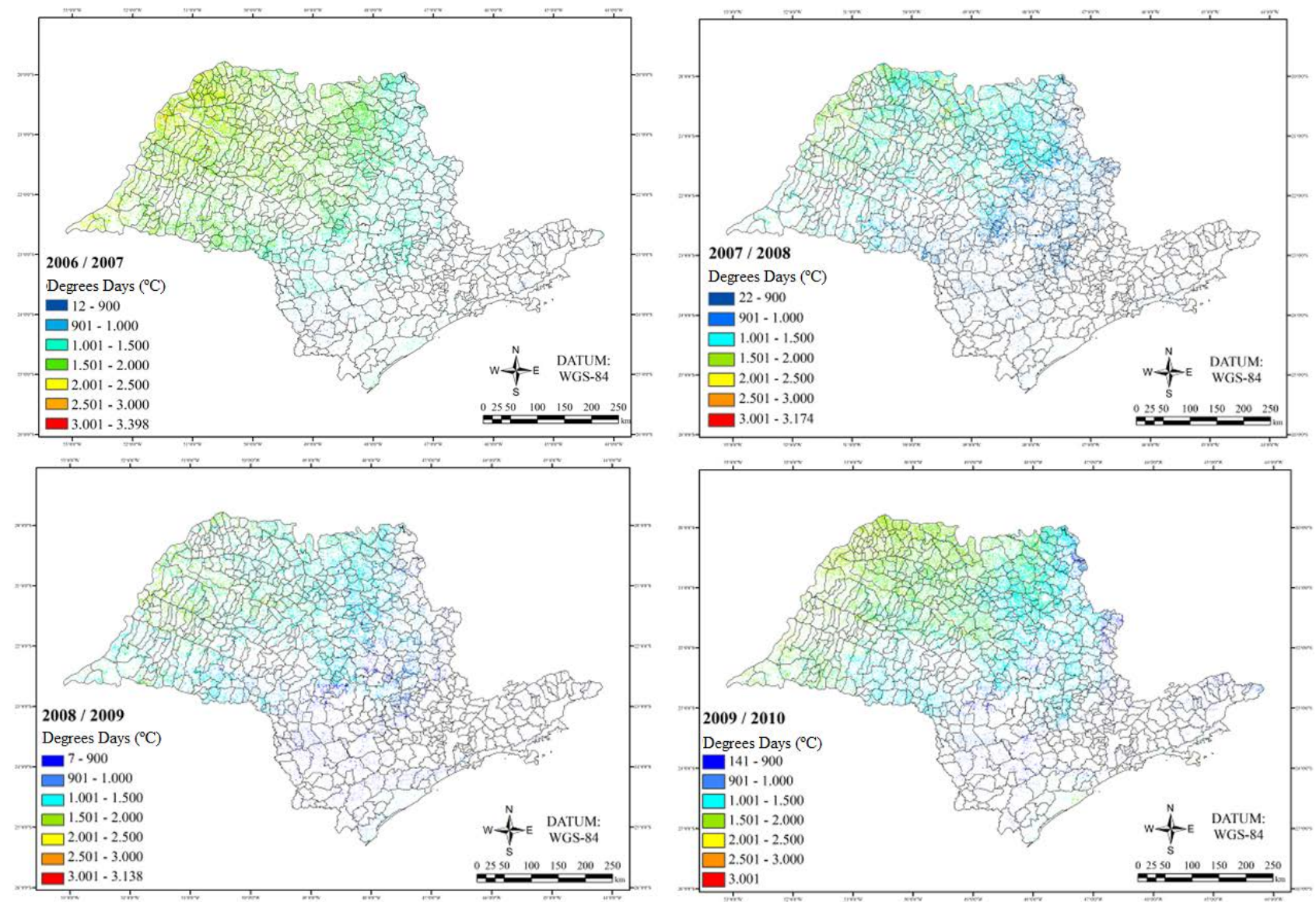

FIGURE 6. Accumulated values of degrees days in ranges of sugar cane growth and harvest in 2006/2007, 2007/2008, 2008/2009 and 2009/2010 obtained from the methodology applied.

MARIN et al. (2008) analyzing the spatial and temporal variability of productive efficiency of sugar cane in São Paulo, concluded that climatic factors explained $43 \%$ of this variability while soil factors only $15 \%$. Thus, there is a high dependency of sugar cane culture in relation to climate variability.

Considering the maps generated in this study, the spatial view, in the state scale, the variability of rainfall, evapotranspiration and global radiation allowed to do analyzes befitting with reality, using only MODIS sensor images and agro-meteorological data derived from the ECMWF model. . From the cycle length, it was possible to realize the impact of their reduction, along with 
the precipitation in the subsequent crop. The knowledge of degree-days for sugar cane in a georeferenced form provides means of viewing the thermal energy consumption of the sugar cane in each region of the state. Thus, from these results, it is suggested for future study, the relationship of these with the productivity of sugar cane, generating estimate models.

\section{CONCLUSIONS}

The information from the MODIS sensor and the ECMWF model allowed knowing the spatial variability of climatic elements and their impacts on the cultivation of sugar cane in São Paulo, consistent with the observed results.

\section{ACKNOWLEDGMENT}

To CAPES for the doctoral scholarship granted to the Faculdade de Engenharia Agrícola (FEAGRI) and the Universidade Estadual de Campinas (UNICAMP) for the opportunity to search.

\section{REFERENCES}

ALMEIDA, A.C.S.; SOUZA, J.L.; TEODORO, I.; BARBOSA, G.V.S.; MOURA FILHO, G.; FERREIRA JÚNIOR, R.A. Desenvolvimento vegetativo e produção de variedades de cana-deaçúcar em relação à disponibilidade hídrica e unidades térmicas. Ciência e Agrotecnologia, v.32, n.5, p.1441-1448, 2008. Disponível em: <http://www.scielo.br/pdf/cagro/v32n5/13.pdf >. Acesso em 14 maio 2012.

AGUIAR, D.A.; RUDORFF, B.F.T.; RIZZI, R.; SHIMABUKURO, Y. E. Monitoramento da colheita da cana-de-açúcar por meio de imagens MODIS. Revista Brasileira de Cartografia, Presidente Prudente, v.60, p.375-383, 2008.

BACCHI, O.O.S.; SOUZA, A.G.C. Minimum threshold temperature for sugarcane growth. In: CONGRESS OF THE INTERNATIONAL SOCIETY OF SUGARCANE TECHNOLOGISTS, 17 $^{\circ}$, 1976, São Paulo. Proceedings... São Paulo, v. 2, p.1733-1741, 1976.

CONAB. Companhia Nacional de Abastecimento. Acompanhamento da Safra Brasileira: Cana-deAçúcar - Safra 2007/2008 - segundo levantamento. Brasília. 2007. Disponível em:

<http://www.conab.gov.br/OlalaCMS/uploads/arquivos/91224c2f99a2af36a9fa3601a0098090..pdf> Acesso em: 24 maio 2012.

CONAB. Companhia Nacional de Abastecimento. Acompanhamento da Safra Brasileira: Cana-deAçúcar - Safra 2008 - segundo levantamento. Brasília, ago. 2008. Disponível em:

<http://www.conab.gov.br/OlalaCMS/uploads/arquivos/7d8871309d6409c9ba38739d4f59d434..pdf >. Acesso em: 24 maio 2012.

CONAB. Companhia Nacional de Abastecimento. Acompanhamento da Safra Brasileira: Cana-deAçúcar - Safra 2009 - segundo levantamento. Brasília, set. 2009a. Disponível em:

<http://www.conab.gov.br/OlalaCMS/uploads/arquivos/9579d4162da214d30b9e86a7881b447c..pdf $>$. Acesso em: 24 maio 2012.

CONAB. Companhia Nacional de Abastecimento. Acompanhamento da Safra Brasileira: Cana-deAçúcar - Safra 2009/2010 - segundo levantamento. Brasília, dez. 2009b. Disponível em:

$<$ http://www.conab.gov.br/conabweb/download/safra/3_levantamento2009_dez2009.pdf.> Acesso em: 25 maio 2012.

CONAB. Companhia Nacional de Abastecimento. Acompanhamento da Safra Brasileira: Cana-deAçúcar - Safra 2010/2011 - segundo levantamento. Brasília, ago. 2011. Disponível em:

<http://www.conab.gov.br/OlalaCMS/uploads/arquivos/ecf76fd96889c63b13 68be8085214377..pdf>. Acesso em: 24 maio 2012.

CONAB. Companhia Nacional de Abastecimento. Acompanhamento da Safra Brasileira: Cana-deAçúcar - Safra 2011/2012 - segundo levantamento. Brasília, ago. 2010. Disponível em: 
<http://www.conab.gov.br/OlalaCMS/uploads/arquivos/11_08_30_13_41_1

9_boletim_cana_portugues_-_agosto_2011_2o_lev..pdf>. Acesso em: 25 maio 2012.

DOOREMBOS, J.; KASSAN, A. H. Yield response to water. Rome: FAO, 1979. 212p. (Irrigation and drainage paper, 33).

FAOSTATS. Food and Agriculture Organization of the United Nations. Statistics Division of the FAO. Disponível em <http://faostat.fao.org/> . Acesso em: 25 maio 2012.

IBGE. Instituto Brasileiro de Geografia e Estatística: Banco de Dados Agregados. Sistema IBGE De Recuperação Automática (SIDRA). Disponível em: <http://www.sidra.ibge.gov.br/> Acesso em: 25 maio 2012.

MARIN, F.R.; LOPES-ASSAD, M.L.; ASSAD, E.D.; VIAN, A.E.; SANTOS, M.C. Sugarcane crop efficiency in two growing seasons in São Paulo State, Brazil. Pesquisa Agropecuária Brasileira (PAB), Brasília, v. 43, n. 11, nov. 2008. Disponível em:

$<$ http://www.scielo.br/scielo.php?pid=S0100-204X2008001100002\&script=sci_arttext $>$. Acesso em: mar. 2012.

MORAES, R. A. Monitoramento e estimativa da produção da cultura de cana-de-açúcar no estado de São Paulo por meio de dados espectrais e agrometeorológicos. Campinas: UNICAMP, 2012a, 115p. Tese Doutorado.

MORAES, R.A.; ROCHA, J.V.; ROLIM, G.; LAMPARELLI, R.A.C.; MARTINS, M. Avaliação dos dados decendiais de precipitação e temperatura máxima e mínima do ar simulados pelo modelo ECMWF para o Estado de São Paulo. Brasilian Journal of Irrigation and Drainage, IRRIGA, Botucatu, v.3, n.17, p.397-407, 2012b.

PEREIRA, A.R.; ANGELOCCI, L.R.; SENTELHAS, P.C. Agrometeorologia: fundamentos e aplicações práticas. Guaíba: Agropecuária, 2002. 478p.

PERSON, A.; GRAZZIANI, F. User guide to ECMWF forecast products. Meteorological Bulletin M3.2, version 4, March, 2007. Disponível em

$<$ http://www.uio.no/studier/emner/matnat/geofag/GEF4220/v09/undervisningsmateriale/Persson_us er_guide.pdf $>$ Acesso em março 2012.

RODRIGUES, J.D. Fisiologia da cana-de-açúcar. Botucatu: Instituto de Biociências, UNESP, 1995.

TRIANA, C.A.R. Energetics of Brazilian ethanol: Comparison between assessment approaches, Energy Policy, v. 39, n. 8, p. 4605-4613, 2011. Disponível em:

<http://www.sciencedirect.com/science/article/pii/S03 01421511003545>. Acesso em: 26 maio 2012.

UDOP - União dos Produtores de Bioenergia. Estatísticas. Disponível em:

$<$ http://www.udop.com.br/download/estatistica/area_cultivada/01mar12_evolucao_produtividade.p df>. Acesso em: 24 maio 2012.

XAVIER A.C.; RUDORFF, B.F.T.; SHIMABUKURO, Y.E.; BERKA L.M.S.; MOREIRA M.A. Multi-temporal analysis of MODIS data to classify sugarcane crop. International Journal of Remote Sensing, Basingstoke, v. 27, n.3-4, p.755-768, 2006. 